\title{
Moral Reasoning in Bodybuilding
}

\author{
Agnė Kelaitytė, Diana Karanauskienè \\ Lithuanian Sports University, Kaunas, Lithuania
}

\begin{abstract}
Background. The aim of the research was to disclose the process of moral reasoning in bodybuilding: to reveal the features of bodybuilding sport (athletes' goals, benefits of the sport and its costs), to find out the circumstances which can affect athletes' moral decisions, to evaluate bodybuilding athletes' moral reasoning strategies, and to reveal athletes' most important moral decisions.

Methods. The study employed qualitative research which involved eight bodybuilding athletes. The respondents were selected using the theoretical purposeful convenience sampling strategy. A semi-structured interview method was used to collect information.

Results. Athletes' goals in bodybuilding can be sports related (getting to know the sport, athletic achievements) or personal (moral and psychological toughness, personal improvement, self-realization, material benefits). Bodybuilders benefit from the sport in physical (health and appearance improvement) and social (gained experience, self-realization) ways. The price of this sport is athletes' hard work, large amounts of money, sacrificed personal life and deterioration of psychological and physical health. Moral reasoning can be influenced by positive circumstances (bodybuilding philosophy, internal beliefs, fighting against cheating, team spirit) and negative (ingrained misdemeanours in sport, corruption, flawed rating system, possibility to avoid responsibility, big price of winning, psychological pressure, inadequate goals). Athletes most often use rational moral reasoning strategies (regarding their beliefs, solution seeking, situational decisions, self-mobilization, setting options, relying on experience). Athletes more often make positive moral decisions (changing the trainer, following the rules, resisting pressure, moral behaviour) than negative (adapting to the situation, acting like the others, winning at any cost).

Conclusions. Bodybuilders most often aim for personal goals. Bodybuilding provides its athletes with physical and social benefits. The price of this sport is bodybuilders' hard work, large sums of money, sacrifice of personal life and health. Certain circumstances might influence athletes to make positive moral decisions while others might influence negative decisions. Bodybuilding athletes use two different moral reasoning strategies: rational or irrational. Bodybuilders' more often make positive moral decisions, but negative decisions occur as well.
\end{abstract}

Keywords: morality, moral reasoning, bodybuilding.

\section{INTRODUCTION}

$\mathrm{S}$ cholars are increasingly interested in moral reasoning in the contexts of sport and everyday life because research shows that it is directly linked to aggression, disputes, surrender and other, often immoral, behaviour (Bredemeier, 1994). Moral decisions are often made in situations where athletes experience difficulties or are likely to have a conflict of interest. According to the author, the context has a decisive influence on moral reasoning. If the context of sport requires aggression, non- condescension, appropriate decisions will be made.

The sport itself is treated differently. Some authors (Long, Pantaléon, Bruant, \& d'ArripeLongueville, 2006) maintain that most people treat sports as an area of financial corruption, doping, violence, or mere fraud. In their view, sport must be transparent, as it is a great opportunity to strengthen morality, to care for national minorities, to teach people to respect and abide by the rules and, more generally, to 
help people become better, but often the opposite is true.

The immoral behaviour of athletes in both sports and personal life is a complex phenomenon influenced by various internal and external factors. Sports fans often forgive high-achieving athletes and tolerate their immoral actions or do not believe that the accusations made against them are justified (Lee, Kwak, \& Braunstein-Minkove, 2015).

The study is based on the principle of moral psychology (Lapsley, 2018) that moral reasoning is closely related to personal identity and moral emotions. Moral emotions are very sensitive to any violation of moral norms. Research shows that people who see others performing criminal actions experience negative moral emotions (Lee, Kwak, \& Braunstein-Minkove, 2015). Such emotions play a crucial role in evaluating criminal behavior and shaping appropriate decisions. Thus, moral judgment is usually based on intuitive emotions rather than conscious moral reasoning.

However, there is no denying that making moral decisions is a cognitive process. People make decisions based on how they perceive morality. Haan (1977, cit. from Long et al., 2006) argues that moral decisions are made in social interactions such as conflicts, dialogues, or various specific situations. Most research in sports science is based on this Haan's theory of moral development. Based on their research, Bredemeier and Shields (1986) argue that the level of moral decision-making in athletes in life situations is much higher than in sport situations, as in many cases the context of sport is very different from the context of life. In sports, the moral atmosphere depends more on external regulation - rules, coach, or referees. Competition also creates a kind of pressure.

Internal regulation is also important. Studies by the same authors (Bredemeier, Shields, Weiss, \& Cooper, 1986) show that moral decisions are driven by athlete characteristics such as his/her level of aggression, age, gender, sports experience, level of athletic fitness, and motivation. The more aggressive an athlete is, the lower his/her level of moral reasoning. The higher athletes' expectations in sports, the more they tend to cheat. More selfish athletes are more likely to cheat for their own benefit than for the benefit of the team.

Researchers agree that most research on athletes' reasoning processes is done from the researchers' perspective, and relatively little - from the perspective of athletes themselves (Stuart,
2003). In order to deeply analyse this complex phenomenon, it is very important to allow athletes to express their own understanding, vision, and perspectives.

The research aim of this study was to reveal the moral reasoning process in bodybuilding sports. For this reason it was very important to reveal the peculiarities of bodybuilding sports (athletes' goals, benefits and costs of this sport), to determine the circumstances that may influence the moral decisions made by bodybuilders, to evaluate bodybuilders' moral reasoning strategies, and finally, to identify the most important moral decisions being made.

\section{METHODS}

Research participants. Research participants in this study were eight 8 athletes in bodybuilding sports. Subjects were selected on the basis of theoretical purposeful, convenience sampling strategy, as this method allows convenient selection of readily available subjects. In accordance with the principle of saturation (Saunders et al., 2017), the interview process was terminated when the respondents' responses no longer provided new information.

Research organization. The study was conducted in February-March, 2020. Respondents were acquainted with the relevance, purpose and course of the study. The research interviews were conducted in public places such as sports clubs or cafes. Some interviews were conducted via social networks with the help of the voice messaging function of the Messenger gadget. This method was chosen due to the overly tight work and training schedule of the study participants.

Informed consent to participate in the study. Each study participant was provided with a written informed consent form to participate in the study. It guaranteed the confidentiality of information, and ensured the respondents the right to decide for themselves whether to terminate the study at any time and without any further explanation.

Methodological strategy guiding the study. The principles of grounded theory were chosen for this study (Bagdonaitė-Stelmokienè \& Žydžiūnaitè, 2016). The grounded theory is based on inductive logic, i. y. the researcher does not start with hypotheses or theory, not with attempts to confirm or disprove it, but - on the contrary - starts with data collection, at the same time analyzing them 
and finally creating a theory, theoretical model or explanation. Various methods are used to collect data, with the main method being an unstructured or semi-structured interview.

Data collection and analysis. The semistructured interview method was chosen for data collection. The interview guide was designed according to the research plan. The obtained answers of the subjects were analysed using the method of qualitative data content analysis (Žydžiūnaitė \& Sabaliauskas, 2017). The data are divided into categories and subcategories, which were illustrated with examples from the interview materials. In the content analysis, the text was read more than once in order to discover certain perceptible categories. Separate semantic units were identified and recorded, and then assigned to subcategories, which were later grouped into larger subcategories and categories.

Research ethics. The study was conducted in compliance with all ethical and legal requirements. Research participants were explained that participation in the study was voluntary, which was confirmed by signing the informed consent form. They were also guaranteed anonymity and confidentiality. The researchers made sure that the interview questions did not disturb the respondents and did not make them feel uncomfortable. Respondents were able to get acquainted with the transcripts of the interviews and the analysed materials and to make sure that the interview data was used honestly, their thoughts were not distorted.

\section{RESULTS}

Peculiarities of bodybuilding sport. Aiming at understanding the lifestyle of bodybuilding athletes, the subjects were asked questions about the peculiarities of their sport. One of the most important factors is the goals the athletes pursue. Respondents' answers to the questions about career goals were twofold: some pursue sports goals, others - personal goals. Athletes pursuing sports goals indicated that they wanted to participate and win prizes in prestigious tournaments and to be the best. However, the majority of respondents indicated that they pursued personal goals in this sport. Athletes stated that they wanted to grow morally and psychologically, improve personally, realize themselves, but also receive material benefits. Many athletes they wanted to improve on their previous results without pursuing achievements. These data are presented in Table 1.

Research participants describing their goals in bodybuilding, it can be stated that athletes more often want to achieve personal goals than sports goals. This means that it is more important for athletes to realize themselves, monitor their personal development, become stronger psychologically, or gain personal material benefits than to earn a title or a trophy.

Table 1. Category: Athletes' goals in bodybuilding

\begin{tabular}{|c|c|c|}
\hline Subcategory & Subcategory/code & Illustrative examples \\
\hline \multirow[b]{2}{*}{ Sports goals } & Knowing the sport & $\begin{array}{l}\text { When I started bodybuilding, my goals were just to see the life of a bodybuilder } \\
\text { from within this sport. }\end{array}$ \\
\hline & Sports achievements & $\begin{array}{l}\text { My goal in this sport, probably like of all athletes, is to be the best... } \\
\text {... there was a great desire to win and achieve the best possible result both in } \\
\text { the body shape and in the competition as well as annual standings... } \\
\text { I would like to be strong enough in the European Championship, get to Top6, } \\
\text { maybe Top3. }\end{array}$ \\
\hline \multirow{4}{*}{ Personal goals } & $\begin{array}{l}\text { Moral and psychological } \\
\text { strength }\end{array}$ & $\begin{array}{l}\text { In bodybuilding, I sought to become stronger morally and psychologically, and } \\
\text { I did. }\end{array}$ \\
\hline & Personal development & $\begin{array}{l}\text { My main goal is to be better each season than I was last season. } \\
\text { My goal in this sport is to have to compete against myself, against nothing } \\
\text { else. Those who chase trophies may seek victory in some other way. My view is } \\
\text { different. } \\
\text {... I am interested in human development. }\end{array}$ \\
\hline & Self-realization & $\begin{array}{l}\text { At the moment, it's just to realize myself, to achieve certain results in } \\
\text { international competitions, of course, as high as possible. I have no } \\
\text { professional goals... }\end{array}$ \\
\hline & Material benefits & $\begin{array}{l}\text { The goal for the future is, perhaps, to make money from it. It is difficult to do it } \\
\text { in Lithuania, but maybe I will go abroad. }\end{array}$ \\
\hline
\end{tabular}


Another very important factor in sports activities is the benefits of sports. The respondents' views can be classified into two groups: physical and social benefits. For some athletes, physical changes, improved health due to strengthening the body, and positive changes in appearance were more important in their sports activities. Other athletes valued social benefits more. It is experience gained in sports activities and the opportunity to realize themselves and to show their hard work (see Table 2).

Summing up, it can be argued that athletes can benefit from bodybuilding in two ways: either physical or social. Another factor that characterizes the peculiarities of sports is the price of sports. The respondents stated that they made a great personal contribution to the preparation for the competition: hard work, great constraints, donated large sums of money, personal life, relationships with significant persons. Many athletes also mentioned the cost of health. They mentioned such physical health disorders as severe weakness, constant feeling of cold, acquired trauma, hormonal imbalance, or developed spinal hernia. This information is presented in Table 3.

Table 2. Category: Benefits of bodybuilding sport

\begin{tabular}{|c|c|c|}
\hline Subcategory & Subcategory/code & Illustrative examples \\
\hline \multirow[t]{2}{*}{ Physical benefits } & Health & $\begin{array}{l}\text { I definitely became stronger physically... } \\
\text {... I can ignore the pain and fatigue... }\end{array}$ \\
\hline & Appearance & ... I changed the body shape so that I am not unnoticed on the street. \\
\hline \multirow{2}{*}{ Social benefits } & Experience gained & $\begin{array}{l}\text { I gained a lot of experience... } \\
\text { And I usually take defeat as a lesson. I can calm myself down. If I'm the fifth, I } \\
\text { say, "Oh, but there were seven athletes, I'm not the last."” I cool down and try } \\
\text { to take a lesson from everything, tell myself what was wrong, what I didn't do } \\
\text { and then drive forward. }\end{array}$ \\
\hline & Self-realization & $\begin{array}{l}\text { For me, my achievement personally is not a trophy. The process is interesting for } \\
\text { me. The very exit to the stage ......you will not change anything when you get up } \\
\text { in the morning. So winning for me is an appreciation of what I did because it's } \\
\text { a complicated process, you struggle with yourself many times. For me, this is a } \\
\text { victory. }\end{array}$ \\
\hline
\end{tabular}

Table 3. Category: The costs of bodybuilding sport

\begin{tabular}{|c|c|c|}
\hline Subcategory & Subcategory/code & Illustrative examples \\
\hline \multirow{3}{*}{$\begin{array}{l}\text { Personal } \\
\text { contribution }\end{array}$} & Hard work & $\begin{array}{l}\text { From my personal experience, I have sacrificed a great deal. My genetics } \\
\text { are not special, so I had to work more than others. My preparation took } \\
\text { much longer and it was very constrained, I lost more than } 17 \mathrm{~kg} \text { before the } \\
\text { competition, which is a lot... }\end{array}$ \\
\hline & Much money & $\begin{array}{l}\text { What did I sacrifice? First of all, huge sums of money that not everyone can } \\
\text { afford, thousands of euros. So, I have to not only play sports, but also I have to } \\
\text { go to work and I have to work long hours to afford it... }\end{array}$ \\
\hline & Sacrificed personal life & $\begin{array}{l}\text { I still sacrificed my personal life because I spent } 3 \text { hours }+ \text { every day in the } \\
\text { hall. It's very damaging to a relationship, but thank God, a little bit. }\end{array}$ \\
\hline \multirow[b]{2}{*}{ Health } & $\begin{array}{l}\text { Deteriorated } \\
\text { psychological health }\end{array}$ & $\begin{array}{l}\text { The psyche falls from that "eternal" diet that doesn't seem to end. So, few } \\
\text { people want to talk to an always irritable person. }\end{array}$ \\
\hline & $\begin{array}{l}\text { Deteriorated physical } \\
\text { health }\end{array}$ & $\begin{array}{l}\text { Co-workers and bosses looked at me suspiciously when they saw that I was barely } \\
\text { walking or in September, when it was still quite warm outside, I was wearing two } \\
\text { winter jackets and a few more clothes, such as a thermal suit. Employers often } \\
\text { wondered if I would be able to do my job, and my employment was at risk ... } \\
\text {... I've personally had injuries, so training again would be a big challenge. I } \\
\text { hope to be able to heal even more in the future, heal injuries, then maybe think } \\
\text { again... } \\
\text { Health decisions are often made in preparation for a competition. It happens } \\
\text { that when you do tests and hormones are very strongly negotiated, then you } \\
\text { have to choose - maybe you will choose to take fewer supplements and not press } \\
\text { yourself so hard. }\end{array}$ \\
\hline
\end{tabular}


Table 4. Category: Positive circumstances

\begin{tabular}{|c|c|}
\hline Subcategory & Illustrative examples \\
\hline $\begin{array}{l}\text { Philosophy of } \\
\text { bodybuilding sport }\end{array}$ & $\begin{array}{l}\text { In my mind, bodybuilding is a sport of respect, bodybuilders respect each other because they know } \\
\text { what a difficult path they have to go. Just as boxing is a gentlemen's sport, so I think bodybuilding } \\
\text { has to be similar to it. }\end{array}$ \\
\hline Internal beliefs & $\begin{array}{l}\text { Well, and inner beliefs ... I was educated correctly, starting with giving girls' priority and ending } \\
\text { with "treating others the way you want to be treated." This I did not support those who psychologi- } \\
\text { cally oppressed others. I tried to be friendly and help everyone who needed my help regardless of } \\
\text { whether he/she was my opponent or not. } \\
\text { Conscience erodes if you do something wrong. In the past, that feeling was stronger, now it is no } \\
\text { longer so. }\end{array}$ \\
\hline Fight against cheating & $\begin{array}{l}\text {... it is practically impossible to cheat in this sport, well, unless by slandering another athlete or } \\
\text { choosing the wrong clothes, the wrong make-up, but the judges immediately "deal" with it, they do } \\
\text { not even allow you to appear on the stage. }\end{array}$ \\
\hline Team spirit & $\begin{array}{l}\text { My team does not cheat, we know all the rules and regulations. No one encourages me to cheat, to } \\
\text { take risks. I only risk my health by preparing, "pressing" my body shape. I don't feel any pressure } \\
\text { from others, I feel pressure from myself. I want to do the maximum myself, no one forces me to do it. } \\
\text { I know that if I don't, I will deceive not others but myself. }\end{array}$ \\
\hline
\end{tabular}

By sacrificing health, athletes run the risk of losing relationships with those around them. There is also a risk of serious health problems, as athletes have often said they do not preserve health and sacrifice it in the name of participating in competitions. Some respondents reported taking a break from sports activities or even stopping them altogether due to injuries. This suggests that in bodybuilding, the main sacrifice of athletes is their health, which can have consequences in later life.

Circumstances that may affect moral reasoning. Moral decisions of athletes can be influenced by certain circumstances. Certain factors can motivate athletes to make positive decisions. One of them is the philosophy of bodybuilding sport. Respondents argued that in bodybuilding, athletes respect each other. Another positive circumstance was athletes' inner beliefs. Research participants indicated that they were proud to be honest, even if they lost, they appreciated the good emotions provided by bodybuilding, and they did not support unethical athletes. Subjects also mentioned the fight against cheating in bodybuilding, claiming that misbehaving competitors are restrained by judges. Another important consideration is the team spirit. Some athletes indicated that no one was cheating on the team they represented, all athletes were familiar with the rules and regulations of the sport. These data are presented in Table 4.

The most common circumstance that encourages positive decisions is their inner beliefs. It encourages athletes to be friendly, to help others, even competitors, not to take prohibited drugs and to be proud of it, to appreciate the feeling of standing on the stage, and to feel unwell if they misbehave. According to the athletes, "Scammers are corrupt and have no moral principles at all. They no longer have even the simplest humanity." Thus, it can be argued that inner beliefs are a very important factor in moral reasoning.

Other circumstances can force athletes to behave negatively. According to respondents, these may be circumstances related to the sport itself, such as long-lasting transgressions in the sport. Some bodybuilding rules are broken by all athletes, even the judges, there is no encouragement to follow them, the majority of bodybuilders use prohibited drugs. Corruption and the subjectivity of judges are also rampant. Athletes see flaws in the rating system, claiming that some judges are old-fashioned and they lack evaluation accuracy. Subjects identify the possibility of not being caught, avoiding liability as a negative circumstance that encourages negative decisions. In their view, doping tests can be avoided, which is why most athletes abuse illicit drugs. The use of these substances is also justified by the complexity of the sports system. Doping is said to be an integral part of this sport and the rules governing its use can be circumvented (Table 5).

Respondents also mention personal circumstances. Considering the high cost of winning, athletes would be determined to do everything they can for a better position in the competition. Athletes say they often face psychological pressure from those around them. Another personal condition that can lead to dishonesty is emphasized - inadequate goals of the athlete. With very high goals, athletes give up their morale to achieve their goals (Table 5). 
Table 5. Category: Negative circumstances

\begin{tabular}{|c|c|c|}
\hline Subcategory & Subcategory/code & Illustrative examples \\
\hline \multirow{5}{*}{$\begin{array}{l}\text { Sports - related } \\
\text { circumstances }\end{array}$} & $\begin{array}{l}\text { Long-lasting transgressions } \\
\text { in the sport }\end{array}$ & $\begin{array}{l}\text { It's just that there are rules in bodybuilding that everyone breaks and it's } \\
\text { a "public secret"... } \\
\text { It just sometimes seems that the rules don't exist at all. There is basi- } \\
\text { cally no organization to encourage compliance. When you come to this } \\
\text { sport, a coach or perhaps a member of the federation introduces you } \\
\text { to the rules, but no one takes on the job to remind you that you need to } \\
\text { follow them ... }\end{array}$ \\
\hline & Corruption in sport & $\begin{array}{l}\text { And undoubtedly corruption. In this sport, it exists and continues to } \\
\text { grow. It's really sad, I think, it's one way to win unfairly. I have partici- } \\
\text { pated in and watched a lot of competitions and sometimes the corrup- } \\
\text { tion is so obvious that I even makes me sick. } \\
\text { It seems to me that when I took part in one competition in autumn, I was } \\
\text { "convicted" because one judge was the coach of my acquaintance and } \\
\text { since we had s conflict with her, he gave me a very low score. }\end{array}$ \\
\hline & Faulty evaluation system & $\begin{array}{l}\text { In my opinion, the evaluation system should be much more accurate } \\
\text { because there are many old-fashioned judges in Lithuania who value } \\
\text { volume rather than body aesthetics. } \\
\text { In this sport before the competition you do not know exactly what the } \\
\text { evaluation criteria will be. There is no accuracy like, say, basketball, } \\
\text { football, tennis. }\end{array}$ \\
\hline & $\begin{array}{l}\text { Opportunity not to be caught } \\
\text { and avoid responsibility }\end{array}$ & $\begin{array}{l}\text { Everyone can always avoid being caught in sports, if they really want } \\
\text { to, it obviously depends on the sport. } \\
\text { Usually, cheating is indirect with us - everyone does it. There is another } \\
\text { form of cheating that, if you go to a famous coach, the judges them- } \\
\text { selves know him better and give him benefits, giving his athletes higher } \\
\text { places. But it is not a direct fraud, no one is bribed, but morally it gets } \\
\text { like a fraud, even though the athlete himself is not to blame for it. }\end{array}$ \\
\hline & $\begin{array}{l}\text { A complicated system in } \\
\text { sport }\end{array}$ & $\begin{array}{l}\text { As I mentioned, since certain drugs are mandatory, it never occurred to } \\
\text { me that it might be otherwise. It's naturally impossible to achieve any- } \\
\text { thing in this sport, so you don't even think about what it would mean to } \\
\text { participate without them. It is impossible without them. }\end{array}$ \\
\hline \multirow{3}{*}{$\begin{array}{l}\text { Personal } \\
\text { circumstances }\end{array}$} & High winning cost & $\begin{array}{l}\text { Well, this world is such that the one who is smarter takes a bigger bite... } \\
\text { Well, and the price of winning in this sport is huge and I paid it, so for } \\
\text { a better position I would do anything that doesn't go beyond my moral } \\
\text { standards. }\end{array}$ \\
\hline & Psychological pressure & $\begin{array}{l}\text { As I mentioned before, psychological pressure does exist. I think this is } \\
\text { one of the possible forms of fraud, because a psychologically pressured } \\
\text { athlete breaks down much more easily, and it is very important in our } \\
\text { sport to stay focused on your goal. Therefore, I would say that psycho- } \\
\text { logical pressure is one form of fraud, at least in my opinion. No one ever } \\
\text { mentions that you have to win, but still, I feel the tension and pressure } \\
\text { that I have to get some kind of medal for participating. }\end{array}$ \\
\hline & Inadequate goals & $\begin{array}{l}\text { It's an individual sport, you do everything for yourself. There is no big } \\
\text { team that teammates will suffer from your decision. When we are very } \\
\text { "on fire" and set very high goals, sometimes morality disappears be- } \\
\text { cause it is important to achieve our goal. }\end{array}$ \\
\hline
\end{tabular}

In terms of the results obtained, sports-related circumstances have the greatest impact on negative behaviour.

Strategies for moral decision making. In order to understand the moral reasoning process of athletes, it is important to elucidate decisionmaking strategies. According to the respondents, these strategies can be rational or irrational. The respondents presented the following rational decision-making strategies: respect for their own beliefs, finding solutions, situational decisions created by the circumstances, self-mobilization, formation of choices, reliance on experience. Irrational decision-making strategies of athletes are unconscious obedience, obedience to team decisions, ignoring deliberations, making impromptu decisions, relying on intuition. These data are presented in Table 6 . 
Table 6. Moral reasoning strategies

\begin{tabular}{|c|c|c|}
\hline Category & Subcategory & Illustrative examples \\
\hline \multirow{6}{*}{ Rational strategies } & Respect for their own beliefs & $\begin{array}{l}\text { No one is forcing me, I make that decision myself. All of this worries me } \\
\text { the most, and other people have their own views on all of this... } \\
\text { We probably all have our limits since childhood, which depends on } \\
\text { education probably: what I can and what I can 't. It is probably an auto- } \\
\text { mated reaction, if in my environment, family, everything was acceptable } \\
\text { to a certain extent your inner perception still allows you so much. }\end{array}$ \\
\hline & Finding solutions & $\begin{array}{l}\text { I don't have a model for making decisions, I just try to always go the } \\
\text { hard way because I know it's the right one. } \\
\text { In my experience, I never had a coach to guide me, I was always prepar- } \\
\text { ing alone, so in case of cheating I would only have to consider myself. }\end{array}$ \\
\hline & Situational solutions & $\begin{array}{l}\text { I would behave the way I am comfortable behaving in that situation. } \\
\text { I take no pressure from the environment, let others do what they do. } \\
\text { Therefore, I would do as I am comfortable in that situation, whether to } \\
\text { cheat or not. }\end{array}$ \\
\hline & Self-mobilization & $\begin{array}{l}\text { I am one of those people who is very strongly mobilized in the face of a } \\
\text { serious problem. There is no more room for fever, iron logic emerges, } \\
\text { you weigh everything. if there is a problem, it needs to be solved. The } \\
\text { mind remains cold enough. }\end{array}$ \\
\hline & Formation of choices & $\begin{array}{l}\text { If I have two paths, then I have to try one. If it satisfies me, I take it, if } \\
\text { not - then I choose the other way ... }\end{array}$ \\
\hline & Relying on experience & $\begin{array}{l}\text { That way out turned out to be better for me because I had more expe- } \\
\text { rience in it, more theoretical and practical knowledge, it was tested } \\
\text { more times. I would say the biggest influence was the advantage of the } \\
\text { acquired knowledge. And I would do the same in the same situation be- } \\
\text { cause I am the one who rely on knowledge and do not act "va bank". }\end{array}$ \\
\hline \multirow{5}{*}{ Irrational strategies } & Unconscious obedience & $\begin{array}{l}\text { From the very beginning, moral decisions were made very simply - by } \\
\text { blindly listening to the first coach ... So, I could choose, I could say } \\
\text { "No," but I did what was told (the coach knows better). }\end{array}$ \\
\hline & Ignoring considerations & $\begin{array}{l}\text { It is not in my sport that I think ... If I have already decided, whatever } \\
\text { situation arises, whether a trauma or life difficulties, I will try to con- } \\
\text { tinue to achieve my goals ... }\end{array}$ \\
\hline & Offhand decisions & $\begin{array}{l}\text { Making critical decisions the way I do is basically the worst way, but } \\
\text { I make the decision here and now, regardless of the possible conse- } \\
\text { quences. } \\
\text { I usually make decisions quite impulsively. } \\
\text { I don't consider } 10 \text { possible scenarios, but just what seems right to me at } \\
\text { the moment... }\end{array}$ \\
\hline & Obedience to team decisions & $\begin{array}{l}\text { Basically, it's better to do nothing alone because, as they say, one is not } \\
\text { a soldier in the field. In this sport, you will have a hard time doing some- } \\
\text { thing alone. If you're on a team, working with a coach, you don't want to } \\
\text { hide something from him, so it's better to discuss everything strategically } \\
\text { with him. If the coach does not agree to do some kind of violation, again, } \\
\text { there may be such an option... }\end{array}$ \\
\hline & Relying on intuition & $\begin{array}{l}\text { It depends on the situation. I usually think quickly, consider other op- } \\
\text { tions. It's hard to say, somehow, when I have to make a choice, I make a } \\
\text { choice. Maybe I rely on intuition. }\end{array}$ \\
\hline
\end{tabular}

It can be argued that athletes choose a wide variety of moral reasoning strategies. Many athletes make decisions irrationally, making decisions on the spot, based on intuition or obeying the influence of the environment. Still, the majority of respondents indicated applying rational strategies. This means that when it comes to making a moral decision, bodybuilders are more likely to respect their beliefs and to mobilize. Some athletes argued that their decisions might depend on the situation. Thus, it can be assumed that moral decisions, although made rationally, can still be negative.

The most important moral decisions made. Respondents were asked about situations in which 
Table 7. The most important moral decisions have been made

\begin{tabular}{|c|c|c|}
\hline Category & Subcategory & Illustrative examples \\
\hline \multirow{4}{*}{ Positive decisions } & $\begin{array}{l}\text { Changing the coach if } \\
\text { needed }\end{array}$ & $\begin{array}{l}\text { The biggest decision I made was to change the coach. I did this because I found } \\
\text { someone who cares about my health, principles, feelings, and personal life. } \\
\text { Let's say, in the first place I chose a person, a friendship, I can trust this } \\
\text { person ... }\end{array}$ \\
\hline & $\begin{array}{l}\text { Compliance with the } \\
\text { rules }\end{array}$ & $\begin{array}{l}\text { Rules are needed not only in bodybuilding. They set boundaries, so I think they } \\
\text { need to be followed ... The so-called Olympic spirit. I support the rules... }\end{array}$ \\
\hline & $\begin{array}{l}\text { Not giving in to } \\
\text { pressure }\end{array}$ & $\begin{array}{l}\text { If, without my knowledge, someone would do it for me, say my coach, I would } \\
\text { even be able to give up my win when I found out. That achievement would } \\
\text { mean nothing to me at all. It's better to take fifth place among high-level } \\
\text { athletes than to take first but cheating in a dirty way.... }\end{array}$ \\
\hline & Act morally & $\begin{array}{l}\text { Sport should be moral. Competition must be limited. } \\
\text { I was pushed by the idea that I can achieve results without doping, so was my } \\
\text { father's encouragement... }\end{array}$ \\
\hline \multirow[t]{3}{*}{ Negative decisions } & $\begin{array}{l}\text { Adapting to the } \\
\text { situation }\end{array}$ & $\begin{array}{l}\text { I don't think that if I do everything according to the rules and others snatch } \\
\text { the victory in dishonest ways, it means I have to go even harder, I have to do it } \\
\text { in a way that snatches the win in fair ways. You just have to do what you have } \\
\text { to do to win. If you lose because others are cheating, then next time either try } \\
\text { to be better or cheat to be better than them. Again, I think it depends on the } \\
\text { situation... } \\
\text { In this sport, as everywhere in life, there is a "herd instinct": as everyone } \\
\text { behaves, so will I. I am in favour of equal opportunities for all. Very much } \\
\text { depends on the situation. Yes, it's better to win honestly and know you've done } \\
\text { everything you could, but.... }\end{array}$ \\
\hline & $\begin{array}{l}\text { Acting like everyone } \\
\text { else }\end{array}$ & $\begin{array}{l}\text { It depends on the form of cheating. If, for example, another athlete used some } \\
\text { make-up that is not allowed, I would use it in the same way. } \\
\text {... Then I would feel more frustrated, feel bitter for a while, but try to forget } \\
\text { it faster and next time even those cheaters would not win a higher place and I } \\
\text { would win against them. Or when I found out they were cheating, I would start } \\
\text { cheating too. }\end{array}$ \\
\hline & Winning at any cost & A true athlete and must strive to win at all costs. \\
\hline
\end{tabular}

they had to make moral decisions. The answers received were divided into two categories: positive and negative decisions. Athletes named the following positive decisions: change the coach if needed, follow the rules, not to give in to pressure, and behave morally. Analysing the answers of the respondents, negative solutions were also found, such as: adapting to the situation, behaving like everyone else, winning at any cost (Table 7).

These results show that bodybuilders make both positive and negative decisions. Positive moral decisions can be related to personal benefit, such as changing the coach to preserve health, or train for a match with someone you can trust in all aspects. Positive decisions made in many were cases related to fair play: athletes decided not to give in to the pressure to cheat, to act morally, and to follow the rules.

Negative decisions in all cases were related to non-compliance with the rules and cheating. Several athletes indicated that they were making decisions to adapt to the situation, to do what needed to be done, even if dishonest means were to be used.
Athletes also mentioned the decision to behave like everyone else - if everyone used prohibited drugs, they decided to use them themselves. Another decision made was to win at any cost. This suggests that athletes' negative moral decisions are closely related to environmental factors, the behaviour of others, but there are athletes who do not succumb to environmental pressures.

\section{DISCUSSION}

The damage of bodybuilding to physical health has been extensively studied by many researchers. High-intensity training has been shown to upset body fluid balance and heart rate variability (Boone et al., 2016). A long-term diet reduces the body's energy required for various physiological functions. This can have a negative effect on hormonal balance, muscle mass, cardiovascular system, and bone mineral density (Fagerberg, 2018). Pre-competition energy restriction has a negative effect on anabolic hormones, may decrease testosterone, IGF-1 and 
insulin levels (Mäestu, Eliakim, Jürimäe, Valter, \& Jürimäe, 2010). Scientists believe that lack of energy can also affect psychology, mood disorders, which can lead to depression. This explains the thoughts expressed by the research participants about any deterioration in health.

Certain circumstances may influence the decision athletes made; some encourage to act positively, others - to act negatively. Although the philosophy of bodybuilding sports, team spirit and the fight against cheating are named as positive circumstances, the most important positive circumstances are internal beliefs. Similar results were obtained in the study by Fisher and Bredemeier (2000). In it, respondents maintain that their morality depends on personal beliefs, upbringing, what is right and what is not, what moral norms are socially acceptable. This shows that internal regulation is very important in the process of making moral decisions. Yildiz (2019) also presents the significance of bodybuilding sports philosophy. It is argued that the very essence of sport is to teach athletes to adhere to sports ethics, not to compete unfairly and on unequal terms.

Respondents identified more circumstances that could have a negative rather than a positive effect. Some of the circumstances are related to bodybuilding itself, like persistent offenses and breaking the rules. According to athletes, many of them use banned drugs, although the rules forbid it because there are opportunities not to be caught and avoid liability, which is also allowed by the complicated bodybuilding system. This information is confirmed by many studies (Brand, Heck \& Ziegler, 2014; Yildiz, 2019). It has been estimated that $83.3 \%$ of bodybuilders use anabolic steroids (Sánchez-Oliver et al., 2019). Avoidance of liability is also addressed in the study by Fisher and Bredemeier (2000). According to athletes, not everyone is equally tested for doping. Research participants said they were poorly informed about the rules and encouraged to follow them. The same data are mentioned in a study by Yildiz (2019), which found that sports federations provided little information related to doping. Also, this study states that bodybuilders are forced to use banned drugs in order to compete on equal basis with competitors. Similar data were provided by our respondents, who stated that knowing about the fraud of the competitors, they also had to cheat themselves to prevent the competitors from gaining an advantage. Among other circumstances that encourage negative decisions, athletes mentioned corruption in sports and a flawed rating system. In their view, the assessment is not always correct, some judges do not assess what should be most important. This problem was also identified in the study by Fisher and Bredemeier (2000), where it is stated that the evaluation system is insufficiently developed, judges have their favourites, and they better evaluate athletes they already know. These data confirm that there are negative aspects in the field of bodybuilding that often force athletes to make negative moral decisions.

The information provided by the respondents showed that negative circumstances could also be influenced by personal conditions. This can be high winning costs, inadequate goals and psychological pressure. According to athletes, setting high goals makes it more important to achieve them than to keep to moral standards. Such data are also provided by Ceglie (2019). His study shows that ego-oriented athletes who care about beating rivals are more likely to behave immorally. Psychological pressure is also a recognized problem. Some respondents saw psychological pressure as a form of cheating, others - as a form of competition. Research also provides dual assessments. Lucidi et al. (2017) argue that only violations of the rules can be considered cheating, but not other morally questionable behaviours, such as psychological pressure on opponents. These data suggest that bodybuilders also face personal circumstances in their sports activities, which encourage athletes to behave immorally.

Another important aspect of moral reasoning is decision-making strategies. It has been found that athletes use two strategies: some make decisions rationally, others - irrationally. Some athletes indicated that in crisis situations they respected their beliefs, looked for solutions, mobilized themselves, evaluated options and made choices, or relied on their experience. Some respondents said that their decision in many cases depended on the situation, they behaved in a way that was convenient for them in that situation. This suggests that in a given situation, athletes can rationally make a decision to cheat or make another negative decision. Other, fewer athletes choose irrational strategies, such as unconscious obedience to the coach or general team decisions, ignoring deliberations, making spontaneous decisions, relying on their intuition. Irrational decision-making is explained in a study by Brand, Heck, and Ziegler (2014). According to the authors, as considering an athlete's personal 
values or the possible consequences of a behaviour is a complicated process, the choice of behaviour is often made quickly and without any considerations. This information shows that most athletes make decisions rationally and only some give in to others or rely on intuition.

The analysis of the most important moral decisions made by athletes showed that positive decisions were not always made. Some research participants indicated that they had to make negative moral decisions, such as adapting to the situation, trying to win at any cost, and behaving the way everyone behaved. Researchers say that most athletes are determined to win at any cost, often cheating in order to achieve the glory, financial gain, and athletic success (Kamis et al., 2016). Nevertheless, the majority of the subjects stated that they made positive moral decisions: they changed the coach to one who was more concerned about the athlete's health and moral standards, decided to follow the rules and behave morally, adequately evaluated themselves, and did not give in to the pressure of others. Fisher and Bredemeier (2000) also argued that athletes' decisions were based on what mattered to them and not to those around them, as each person has personal standards and different understandings of what is right and what is not. These data suggest that bodybuilders are more likely to make positive moral decisions, but cheating in the name of victory is also a potential phenomenon.

\section{CONCLUSIONS}

1. In bodybuilding, athletes are usually driven by personal goals, such as the desire to realize themselves, personal development, moral and psychological strength, and material gain. This sport can provide two benefits: physical (improvement of appearance or health) or social (experience gained, self-realization). Bodybuilding also comes at a price. Athletes work hard, spend large sums of money, sacrifice their personal lives and their health.

2. The moral decisions of athletes can be influenced by a variety of circumstances. Bodybuilding sports philosophy, athlete's inner beliefs, the fight against cheating in sport and team spirit can lead to positive moral decisions. Sportsrelated circumstances, such as long-standing bodybuilding offenses, corruption, a flawed rating system, the ability to avoid liability, and a complex sports system, can influence negative moral reasoning. Personal circumstances can have the same effect: high cost of winning, psychological pressure, or inadequate goals.

3. Athletes use different decision-making strategies. Some athletes make decisions rationally, i.e. they keep to their beliefs, seek solutions, make decisions depending on the situation, mobilize themselves, evaluate options and make choices, or rely on their experience. Other athletes rely on irrational strategies: they unconsciously obey coaches or team decisions, ignore considerations, make spontaneous decisions, or rely on intuition.

4. The moral decisions made by bodybuilders are usually positive: to change the coach, to follow the rules, not to give in to pressure, to behave morally. Nevertheless, there are also negative decisions made, such as adapting to the situation, behaving like everyone else, winning at any cost.

\section{REFERENCES}

Bagdonaitė-Stelmokienė, R., \& Žydžiūnaite, V. (2016). Grindžiamosios teorijos tyrimo priemonių sudarymas: procesas, parametrai ir rezultatai. Pedagogika, 124(4), 80-91.

Boone, C. H., Hoffman, J. R., Gonzalez, A. M., Jajtner, A. R., Townsend, J. R., Baker, K. M., ... \& Stout, J. R. (2016). Changes in plasma aldosterone and electrolytes following high-volume and high-intensity resistance exercise protocols in trained men. Journal of Strength and Conditioning Research, 30(7), 1917-1923. doi: 10.1519/JSC.0000000000001276

Brand, R., Heck, P., \& Ziegler, M. (2014). Illegal performance enhancing drugs and doping in sport: A picture-based brief implicit association test for measuring athletes' attitudes. Substance Abuse Treatment, Prevention, and Policy, 9(1), 7. doi: 10.1186/1747-597X-9-7

Bredemeier, B. J. L. (1994). Children's moral reasoning and their assertive, aggressive, and submissive tendencies in sport and daily life. Journal of Sport \& Exercise Psychology, 16, 1-14.

Bredemeier, B. J., \& Shields, D. L. (1986). Game reasoning and interactional morality. The Journal of Genetic Psychology, 14, 257-275. https://doi.org/10.10 80/00221325.1986.9914499

Bredemeier, B. J., Shields, D. L., Weiss, M. R., \& Cooper, B. A. B. (1986). The relationship of sport 
involvment with children's moral reasoning and aggression tendencies. Journal of Sport Psychology, 8, 304-318. https://doi.org/10.1123/jsp.8.4.304

Ceglie, F. (2019). Dispositional factors and sportsmanship in italian athletes. Sport Mont, 17(3), 109-112.

Fagerberg, P. (2018). Negative consequences of low energy availability in natural male bodybuilding: A review. International Journal of Sport Nutrition and Exercise Metabolism, 28(4), 385-402. doi: 10.1123/ ijsnem.2016-0332

Fisher, L. A., \& Bredemeier, B. J. (2000). Caring about injustice: The moral self-perceptions of professional female bodybuilders. Journal of Sport and Exercise Psychology, 22(4), 327-344.

Kamis, D., Newmark, T., Begel, D., \& Glick, I. D. (2016). Cheating and sports: History, diagnosis and treatment. International Review of Psychiatry, 28(6), 551-555. http://dx.doi.org/10.1080/09540261.2016.120 8162

Lee, J. S., Kwak, D. H., \& Moore, D. (2015). Athletes' transgressions and sponsor evaluations: A focus on consumers' moral reasoning strategies. Journal of Sport Management, 29(6), 672-687.

Long, T., Pantaléon, N., Bruant, G., \& d'ArripeLongueville, F. (2006). A qualitative study of moral reasoning of young elite athletes. The Sport Psychologist, 20(3), 330-347. https://doi.org/10.1123/tsp.20.3.330
Lucidi, F., Zelli, A., Mallia, L., Nicolais, G., Lazuras, L., \& Hagger, M. S. (2017). Moral attitudes predict cheating and gamesmanship behaviors among competitive tennis players. Frontiers in Psychology, 8, 571. https://doi. org/10.3389/fpsyg.2017.00571

Mäestu, J., Eliakim, A., Jürimäe, J., Valter, I., \& Jürimäe, T. (2010). Anabolic and catabolic hormones and energy balance of the male bodybuilders during the preparation for the competition. The Journal of Strength \& Conditioning Research, 24(4), 1074-1081. doi: 10.1519/JSC.0b013e3181 cb6fd3

Saunders, B., Sim, J., Kingstone, T., Baker, S., Waterfield, J., Bartlam, B., ... \& Jinks, C. (2018). Saturation in qualitative research: Exploring its conceptualization and operationalization. Quality \& Quantity, 52(4), 18931907. https://doi.org/10.1007/s11135-017-0574-8

Stuart, M. E. (2003). Moral issues in sport: The child's perspective. Research Quarterly for Exercise and Sport, 74, 445-455. https://doi.org/10.1080/02701367.2003.10 609114

Yildiz, Ö. (2019). The views of elite bodybuilding athletes concerning doping training, their level of knowledge about doping, and values education in sport. World Journal of Education, 9(1), 56-63. doi: 10.5430/ wje.v9n1p56

Žydžiūnaitè, V., \& Sabaliauskas, S. (2017). Kokybiniai tyrimai: principai ir metodai: vadovèlis socialiniu mokslu studiju programu studentams. Vilnius: Vaga. 